\title{
The role of deep vadose zone water in tree transpiration during drought periods in karst settings - insights from isotopic tracing and leaf water potential
}

Accepted in Science of the Total Environment in September 2019

https://www.sciencedirect.com/science/article/pii/S0048969719343232

\author{
Authors: \\ Simon Damien Carrière ${ }^{1}$, Nicolas K. Martin St-Paul ${ }^{2}$, Coffi Belmys Cakpo ${ }^{3}$, Nicolas Patris ${ }^{4}$, Marina \\ Gillon $^{5}$, Konstantinos Chalikakis ${ }^{5}$, Claude Doussan ${ }^{1}$, Albert Olioso ${ }^{1}$, Milanka Babic ${ }^{5}$, Arnaud \\ Jouineau ${ }^{2}$, Guillaume Simioni ${ }^{2}$, Hendrik Davi ${ }^{2}$ \\ ${ }^{1}$ INRA, UMR 1114 EMMAH, Domaine Saint Paul, INRA Centre de recherche PACA, 228 route de l'Aérodrome, CS 40509, Domaine \\ Saint-Paul, Site Agroparc, France, \\ ${ }^{2}$ INRA, URFM, , Domaine Saint Paul, INRA Centre de recherche PACA, 228 route de l'Aérodrome, CS 40509, Domaine Saint-Paul, \\ Site Agroparc, France, \\ ${ }^{3}$ INRA, PSH, , Domaine Saint Paul, INRA Centre de recherche PACA, 228 route de l'Aérodrome, CS 40509, Domaine Saint-Paul, \\ Site Agroparc, France, \\ ${ }^{4}$ IRD, Hydroscience Montpellier, 300 Avenue du Professeur Emile Jeanbrau, 34090 Montpellier, France, \\ ${ }^{5}$ UAPV, UMR 1114 EMMAH, 301 rue Baruch de Spinoza, BP 2123984911 Avignon Cedex 9, France.
}

\begin{abstract}
Karst environments are unusual because their dry, stony and shallow soils seem to be unfavorable to vegetation, and yet they are often covered with forests. How can trees survive in these environments ? Where do they find the water that allows them to survive? This study uses midday and predawn water potentials and xylem water isotopes of branches to assess tree water status and the origin of transpired water. Monitoring was conducted during the summers of 2014 and 2015 in two dissimilar plots of Mediterranean forest located in karst environments. The results show that the three monitored tree species (Abies alba Mill, Fagus sylvatica L, and Quercus ilex L.) use deep water resources present in the karst vadose zone (unsaturated zone) more intensively during drier years. Quercus ilex, a species welladapted to water stress, which grows at the drier site, uses the deep water resource very early in the summer season. Conversely, the two other species exploit the deep water resource only during severe drought. These results open up new perspectives to a better understanding of ecohydrological equilibrium and to improved water balance modeling in karst forest settings.
\end{abstract}




\section{1-Introduction:}

Changes in temperature and rainfall patterns across many forest ecosystems are expected to increase the risk of drought-induced tree mortality (Allen et al. 2010). Tree resistance to drought is therefore of concern to scientists (Chaves et al. 2002; Breda et al. 2006) and stakeholders (Spies et al. 2010; Keenan 2015). To cope with drought, trees have developed various strategies at different time scales.

Stomata closure is a universal process designed to limit transpiration (Limousin et al. 2010), avoid water potential drop, and prevent irreversible damage caused by embolism to the plant hydraulic system (Martin-StPaul et al. 2017). Other mechanisms that take place at longer time scales involve changes in leaf area to decrease water consumption (Limousin et al. 2009, van Hees 1997, Martin-StPaul et al. 2013). Instead of regulating water loss, trees can also take up water from groundwater when the water table is accessible (e.g. Murray et al. 2003; Naumburg et al. 2005; Querejeta et al. 2007). This process helps to maintain transpiration and carbon assimilation rates and limits water potential drop and cavitation risk during drought (Rambal et al. 1984; Breda et al. 2006; Abrams et al. 1990; McElrone et al 2004; Johnson et al. 2014). However, several examples in the literature show that despite extremely dry shallow resource conditions ( $\theta_{\text {soil }}<0.5 \% \Psi_{\text {soil }}<-7 \mathrm{MPa}$, respectively, Rambal 1984; Plaut et al. 2012$)$ and a water table that is inaccessible (>100 $\mathrm{m}$ ) to root prospection (Canadell et al. 1996), trees can continue to transpire. Increased biomass allocation to roots is also observed (van Hees 1997). This makes it possible to tap water from deeper resources (Fig. 1b) during the dry season and thus to sustain water fluxes. How does this deep water reservoir contribute to transpiration throughout drought periods?

To explain summer tree survival in karst environments, it seems necessary to invoke deep water exploitation. Karst environments (Martel 1902; Cvijic 1960; Bakalowicz 2005) are rocky and often have steep landscapes resulting from the weathering of carbonate or evaporitic rocks. These landscapes are common world-wide (Chen et al. 2017), especially around the Mediterranean Sea (Bakalowicz and Dörfliger 2005). Soils in karst environments are generally poorly developed and rocky or even absent (Fig 1) and karst's high permeability causes these environments to be generally dry and apparently not wellsuited for vegetation development. Due to their low productivity, karst landscapes are rarely cultivated and are often covered with forest. These ecosystems are crucial because they constitute the recharge areas of karst aquifers that supply water to a large part of the world's population (e.g. $50 \%$ in Austria, $30 \%$ in Belgium, (Hartmann et al. 2014)). Karst hydrosystems have high water storage capacity in the saturated zone (Ford and Williams 2007) and in the vadose zone (Fig. 1a). In the vadose zone, water storage can occur in: i) superficial horizons called epikarst, composed of soil and weathered rock (e.g. Perrin et al. 2003; Aquilina et al. 2006); or ii) deeper horizons (e.g. Emblanch et al. 2003; Carrière et al. 2016). However, the total soil available water (TSAW) generally measured via pedologic pits in these environments is low (a few tens of $\mathrm{mm}$ ) and does not explain vegetation transpiration during drought periods. 

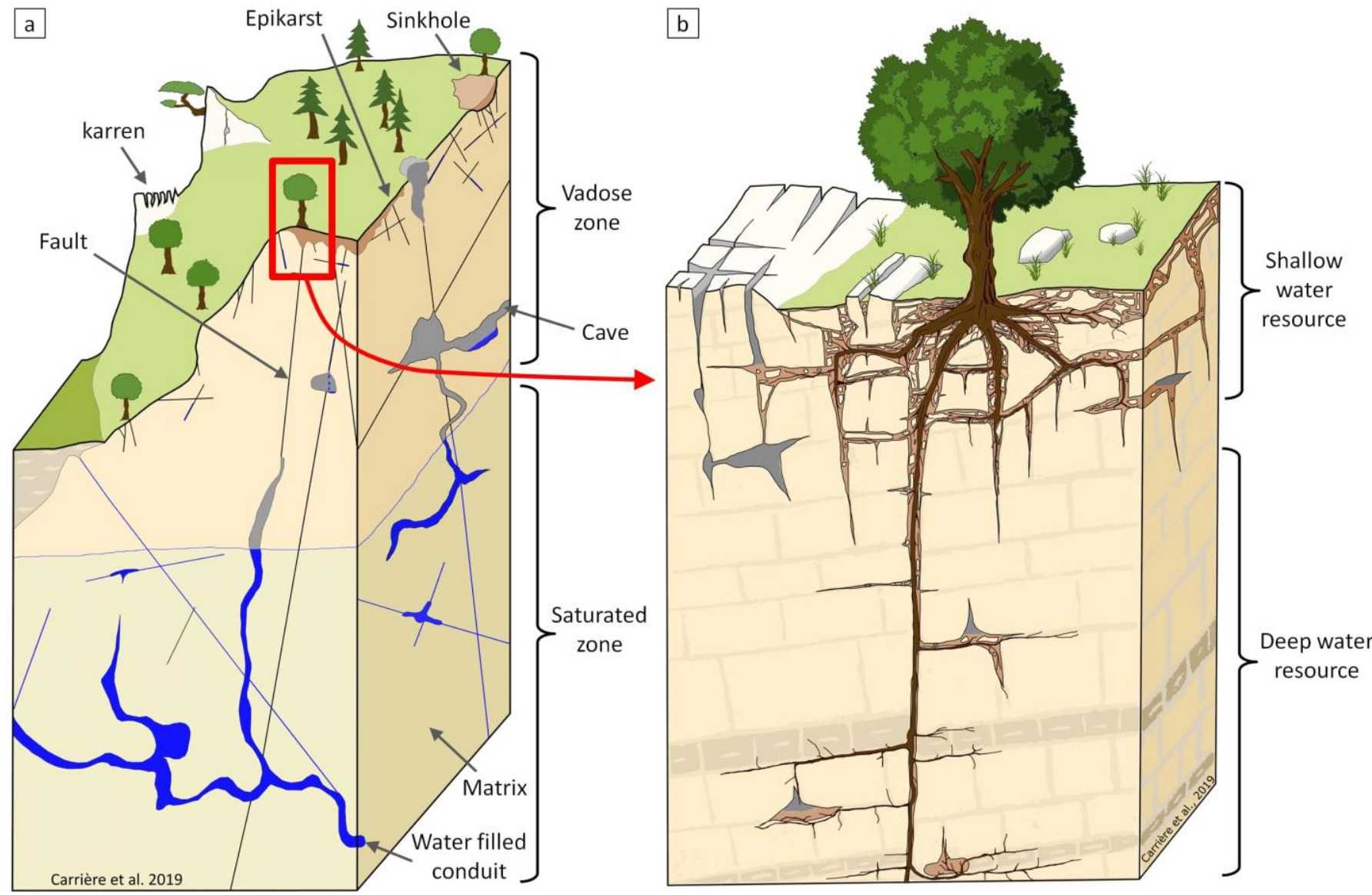

Figure 1: Conceptual diagram of (a) a karst hydrosystem, (b) water reservoirs available for trees in a karst setting: (i) shallow water resource in soil and weathered rock; (ii) deep water resource in the karst vadose zone.

In the three last decades, stable isotope ratios of hydrogen $\left(\delta^{2} \mathrm{H}\right)$ and oxygen $\left(\delta^{18} \mathrm{O}\right)$ have been used to determine the source of water uptake by plants from soil, streams, and groundwater (e.g. Ehleringer and Dawson 1992; Bariac et al. 1994; Walker and Brunel 1990; Olge et al. 2014; Barbeta et al. 2015; Evaristo et al. 2015). It has been hypothesized that water that enters roots is not isotopically fractionated with respect to soil water (Dawson and Ehleringer 1991; Zimmermann et al., 1966). This idea has led many authors to use deconvolution to estimate the mixing ratio of xylem water between two pools (e.g. Dawson 1993; Phillips and Ehleringer 1995) or three pools (e.g. Parnell et al. 2010; Barbeta et al. 2015). However, earlier studies show that in halophyte and xerophyte plants (Sternberg and Swart 1987; Lin and Sternberg 1993; Ellsworth and Williams 2007) and avocado (Persea americana) trees (Vargas et al. 2017), $\delta^{2} \mathrm{H}$ isotopic fractionation can occur during root water uptake. This isotopic fractionation of $\delta^{2} \mathrm{H}$ is noted in many studies (e.g. Brooks et al. 2010; Bertrand et al. 2014; Barbeta et al. 2015; Evaristo et al. 2016; Bowling et al. 2017; Evaristo et al. 2017; Geris et al. 2017). Fortunately, this fractionation effect has a disproportionately greater effect on $\delta^{2} \mathrm{H}$ than on $\delta^{18} \mathrm{O}$ (Ellsworth and Williams 2007; Vargas et al. 2017). Moreover, Barbeta et al. (submitted) have shown that mixing proportion calculations performed with $\delta^{18} \mathrm{O}$ data provide consistent results when the $\delta^{2} \mathrm{H}$ estimation is distorted. 
Leaf or stem water potential is a widely used proxy for plant water stress (Turner 1981). The more negative the leaf water potential, the greater the stress on the plant. Leaf water potential is generally measured with a Sholander pressure bomb (Sholander et al. 1965) but can also be measured with psychrometers to conduct continuous potential measurements (Taylor-Laine et al. 2016). Leaf water potential measured at predawn $\left(\Psi_{\mathrm{P}}\right)$ is generally considered representative of soil water potential in the rhizosphere (Tardieu et al. 1990; Brisson et al. 1993). Leaf water potential at midday $\left(\Psi_{M}\right)$ depends not only on the soil water potential but also on plant hydraulic conductance and the evapotranspiration (ET) demand based on the Ohm's law analogy (Brisson et al. 1993; Olioso et al 1996; Cruiziat et al. 2002; Martínez-Vilalta et al. 2014). Hence, the difference between predawn water potential and midday water potential $(\Delta \Psi)$ provides information about the sap flow driving force and indirectly the transpiration level (Brisson et al. 1993; Cruiziat et al. 2002). The greater the $\Delta \Psi$, the more the trees transpire; the smaller the $\Delta \Psi$, the less the trees transpire.

Used independently, the two approaches presented above make it possible to determine the origin of water and the tree stress level, respectively. In this study we combine isotopic tracing and leaf water potential to determine if it is possible to relate extraction depth to stress level. For this reason, our measurements were done during two summer periods (2014-2015) in two forest types located on Mediterranean karst. One is a mountain forest ( 1340 m.a.s.l.) dominated by Abies alba and Fagus sylvatica trees, and the other, at lower elevation (530 m.a.s.I.), is a typical Mediterranean ecosystem covered by Quercus ilex. We sampled xylem water from three tree species, as well as shallow and deep water in the karst vadose zone for $\delta^{18} \mathrm{O}$ analysis. The main goal of this experiment was to answer the following three questions:

(i) Do trees use deep karst water from the vadose zone during the dry season?

ii) How does deep water use by trees vary according to the level of water deficit?

iii) Does deep water uptake by trees vary among species?

In this project, we used tools from ecology to improve our understanding of how karst systems function. We hypothesize that vegetation may use water from the "deep" vadose zone (between a few meters and few tens of meters) to increase its resilience to drought. This article aims to provide a functional view of the interactions between vegetation and groundwater in the deep vadose zone.

\section{2- Material and methods:}

Experimental site location

The experimental sites are located within the Fontaine de Vaucluse (FdV - France) karst hydrosystem, which hosts one of the largest karst springs in Europe (Fig.2b; Cognard-Plancq et al., 2006; Jourde et al. 2018). This recharge area covers $1162 \mathrm{~km}^{2}$ (Ollivier et al. 2019) and has a broad elevation gradient, making it possible to find a variety of tree species with differing drought resistance. The FdV observatory is part of OZCAR (http://www.ozcar-ri.org/), the French network of critical zone observatories. We selected two experimental sites: i) one in the southern part of the FdV recharge area near Rustrel village at an elevation of $530 \mathrm{~m}$, and ii) one in the northern part of the FdV recharge area, on the northern slope of Mont Ventoux at an elevation of $1340 \mathrm{~m}$. Table 1 summarizes the characteristics of each site. 


\begin{tabular}{|c|c|c|c|c|c|c|c|c|c|c|}
\hline NAME & COORDINATES & $\begin{array}{l}\text { HOLM OAK } \\
\text { BASAL } \\
\text { AREA (\%) }\end{array}$ & $\begin{array}{l}\text { SILVER FIR } \\
\text { BASAL } \\
\text { AREA (\%) }\end{array}$ & $\begin{array}{c}\text { BEECH } \\
\text { BASAL } \\
\text { AREA (\%) }\end{array}$ & $\begin{array}{c}\text { PLOT } \\
\text { SIZE (M) }\end{array}$ & $\begin{array}{c}\text { COARSE } \\
\text { FRACTION } \\
\text { IN SOIL (\%) }\end{array}$ & $\begin{array}{l}\text { SOIL } \\
\text { DEPTH } \\
\text { (CM) }\end{array}$ & $\begin{array}{c}\text { MEAN } \\
\text { ANNUAL } \\
\text { RAINFALL } \\
\text { (MM) }\end{array}$ & $\begin{array}{c}\text { NUMBER } \\
\text { OF PITS }\end{array}$ & $\begin{array}{c}\text { GROUND- } \\
\text { WATER }\end{array}$ \\
\hline RUSTREL & $\begin{array}{c}43^{\circ} 56^{\prime} 12.15^{\prime \prime} \mathrm{N} \\
5^{\circ} 27^{\prime} 58.18^{\prime \prime} \mathrm{E} \\
530 \text { m.a.s.l. }\end{array}$ & 85 & 0 & 0 & $150 \times 50$ & $50-60$ & $0-70$ & 909 & 3 & $\begin{array}{l}\text { Point D } \\
\text { Point C }\end{array}$ \\
\hline $\begin{array}{c}\text { MONT } \\
\text { VENTOUX }\end{array}$ & $\begin{array}{c}44^{\circ} 10^{\prime} 43.93^{\prime \prime} \mathrm{N} \\
5^{\circ} 14^{\prime} 36.85^{\prime \prime} \mathrm{E} \\
1340 \text { m.a.s.l. }\end{array}$ & 0 & 86.3 & 13.7 & $100 \times 100$ & $48-63$ & $50-60$ & 1258 & 4 & $\begin{array}{l}\text { MtS and } \\
\text { Ctr } \\
\text { springs }\end{array}$ \\
\hline
\end{tabular}

Table 1: Main characteristics of the experimental sites. MtS and Ctr are Mont Serein and Contrat springs, respectively, and point $D$ and point $C$ are two seepages monitored within the Rustrel underground laboratory (http://lsbb.eu/presentation/).

\section{Environmental and groundwater settings}

The Rustrel forest is dominated by a sparse evergreen overstory of holm oak (Quercus ilex L.), which represents more than $85 \%$ of the basal area (Carrière et al. 2017). The dominant tree height is about $4 \mathrm{~m}$. The understory is a sparse shrubby layer which represents $15 \%$ of the basal area and includes Buxus sempervirens L., Juniperus communis L., and Juniperus phoenicea L. (Carrière et al. 2017). In this paper, we study only the holm oak on a plot of $150 \times 50 \mathrm{~m}$ at the Rustrel site.

The stand located on Mont Ventoux's northern slope is dominated by silver fir (Abies alba Mill.) (86.3\% of the basal area) and beech (Fagus sylvatica L.) (13.7\% of the basal area). The dominant tree height is about $17.7 \mathrm{~m}$. Our study was conducted on a plot of approximately $100 \times 100 \mathrm{~m}$. This plot was previously studied in detail by Nourtier et al. (2014). They used ground-based geophysics (electrical resistivity tomography (ERT)) to characterize soil conditions and to relate silver fir mortality to drought.

The two sites are located on similar karstified Cretaceous limestone. The subsurface karst at the Rustrel site is complex and heterogeneous due to numerous faults and karst features described in detail by Carrière et al. (2013). Carrière et al. (2016) used multiple geophysical techniques (ERT, Magnetic Resonance Sounding (MRS), Gravimetry) to show that mobile water is stored in the karst vadose zone down to $90 \mathrm{~m}$, as demonstrated by significant seasonal water content variations. At both sites, the saturated water zone of the Fontaine de Vaucluse aquifer is inaccessible to trees; the water table is approximately $400 \mathrm{~m}$ below surface at Rustrel and $1200 \mathrm{~m}$ deep at Mont Ventoux.

At both sites, the karst vadose zone isotopic signal is provided by underground seepage and springs. At Rustrel, two seepage zones named "point D" and "point C" (at $33 \mathrm{~m}$ and $256 \mathrm{~m}$ below the surface, respectively) have been monitored since 2003 (Garry et al. 2008; Blondel et al. 2010) in the Low Noise Underground Laboratory tunnel (http://Isbb.eu/presentation/). At the Mont Ventoux site, two springs are present: Mont Serein spring (MtS), located at a distance of $1.6 \mathrm{~km}$ from the experimental plot (44 $10^{\circ} 51.47^{\prime \prime} \mathrm{N} ; 5^{\circ} 15^{\prime} 48.25^{\prime \prime} \mathrm{E} ; 1446$ m.a.s.l.), and Contrat spring (Ctr) located at a distance of $3 \mathrm{~km}$ (44¹1'03.83" N; 5¹6'51.24" E; 1395 m.a.s.l.).

Soils at both sites are shallow and rocky rendzina has developed due to the karst settings and slope. At Rustrel, the soil contains 50 to $60 \%$ coarse elements and its thickness is relatively variable (from 0 to $70 \mathrm{~cm}$ ). The total soil available water (TSAW), estimated according to the Baize and Jabiol (2011) 
protocol, ranges between 0 and $65 \mathrm{~mm}$. At Mont Ventoux, the soil contains 48 to $63 \%$ coarse elements and its thickness ranges from 50 to $60 \mathrm{~cm}$; TSAW ranges between 45 and $50 \mathrm{~mm}$ (table 1).

The climate at both sites is Mediterranean, characterized by cool and wet winters, hot and dry summers, and a high inter-annual variability (see SI1). The two sites differ in terms of temperature and precipitation due to the elevation difference. Between 2003 and 2015, annual rainfall at Rustrel ranged from 407 to $1405 \mathrm{~mm}$ with a mean value of $909 \mathrm{~mm}$, while the mean annual temperature was $12.9^{\circ} \mathrm{C}$. At Mont Ventoux, annual rainfall ranged from 818 to $1842 \mathrm{~mm}$ during the same period and its mean value was $1258 \mathrm{~mm}$, while the mean annual temperature was $6.53^{\circ} \mathrm{C}$.

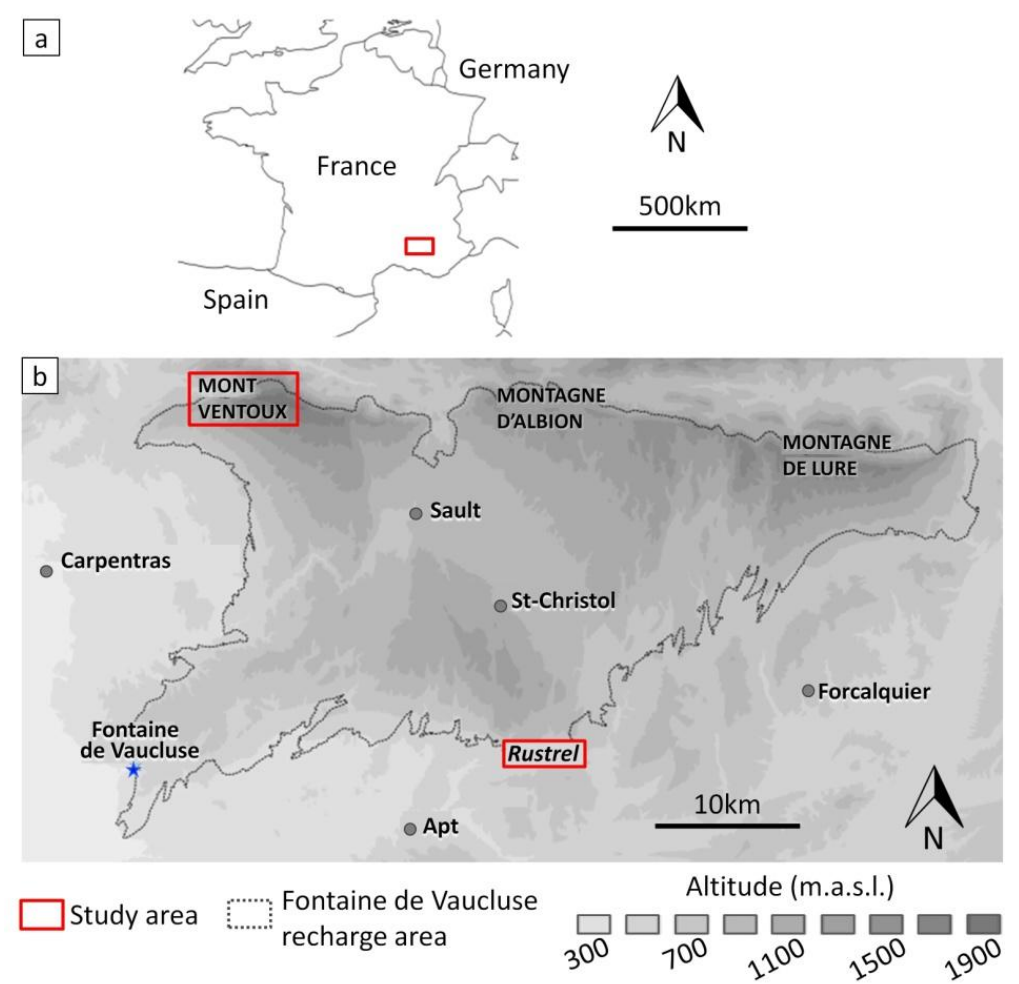

Figure 2: (a) The Fontaine de Vaucluse recharge area located in southeastern France; (b) The experimental sites, Mont Ventoux at $1340 \mathrm{~m}$ and Rustrel at $530 \mathrm{~m}$ are located in the Fontaine de

Vaucluse recharge area. They cover areas of $100 \mathrm{~m} \times 100 \mathrm{~m}$ and $150 \mathrm{~m} \times 50 \mathrm{~m}$, respectively.

\section{Isotopic sampling}

Field work was conducted between July 2014 and August 2015, to sample two successive summer periods. The xylem isotopic signal was sampled on 3 to 5 trees every 1 to 2 months. Three to four sunny branches were collected from each tree at midday. Bark and phloem were removed to prevent interference with enriched water from the leaves. The twigs were immediately packed in parafilm and placed individually in sealed vials and then transferred in a portable cooler to prevent evaporation. All samples were stored frozen at the laboratory until water was extracted and analyzed. A punch was used to sample xylem from the trunk on one date (June 2015) at each site (Mont Ventoux and Rustrel). Sample conservation was similar to that of the stems. The shallow water isotopic signal was collected from precipitation and drainage water every 1 to 3 weeks. Precipitation was collected by pluviometer and stored in containers installed in a pit sheltered from light to limit temperature variations. In addition, 
these containers were equipped with an atmospheric pressure capillary in accordance with the IAEA protocol (IAEA 2014) to limit exchanges between collected water and the atmosphere (see figure SI2). At each site, drainage water was collected at $20 \mathrm{~cm}$ below the surface through a mini-lysimeter directed to a container similar to those used for precipitation (see figure in S12). We chose to collect drainage water because the subsurface is too rocky for auger drilling or porous candle sampling.

Initially, rain and drainage water were analyzed separately, and because the two trends were similar, the two values were merged (arithmetical average) to represent the "shallow water" signal (Fig. 1) in figures 3 and 4. Deep water was collected at two points for each site: i) seepage points D and C for Rustrel, ii) the Contrat spring ( $\mathrm{Ctr}$ ) and the Mont Serein spring (MtS) at the Mont Ventoux site. For each site, these two points were merged to represent the "deep water" signal (Fig. 1) of the karst vadose zone in figures 3 and 4 . We assume that this deep water represents the rock moisture described by Bowling et al. (2017) and Geris et al. (2017).

\section{Leaf water potential}

The leaf water potential was measured at predawn $\left(\Psi_{\mathrm{P}}\right)$ and at midday ( $\Psi_{\mathrm{M}}$ or minimum) for 10 individuals of each species on different dates throughout the summer seasons (June to September) of 2014 and 2015, using a Scholander pressure bomb. Samples for minimum water potentials were collected from sunny branches when the weather was not cloudy. On each date and for each tree, at least three leaves were sampled, immediately placed in a plastic bag saturated with water vapor (by blowing into the bag), and stored in a cooler until measurement. Measurements were made less than one hour after sampling. Two of the three leaves were measured and the third was measured only if a difference greater than $0.2 \mathrm{MPa}$ was found between the two first measurements.

\section{Water extraction and isotopic analyses}

Water from xylem samples was extracted by cryogenic vacuum distillation (Ehleringer and Osmond 1989; West et al. 2006). The stems were quickly cut into small pieces and placed in a flask heated to 90 to $100{ }^{\circ} \mathrm{C}$ for 1 hour. The water was collected in two successive liquid nitrogen traps. Generally, 3 to $5 \mathrm{ml}$ of xylem water was extracted. These liquid samples were stored in small vials until analyzed.

Precipitation and deep water samples were analyzed on a Los Gatos Isotope Ratio Infrared Spectrometer (IRIS) at the University of Avignon (LGR DLT-100 liquid water stable analyzer accuracy $\pm 0.2 \%$ vs V-SMOW for $\left.\delta^{18} \mathrm{O}\right)$. However, because of possible spectral perturbations of IRIS measurements due to organic contaminants in xylem and drainage samples (Martín-Gómez et al. 2015), $\delta^{18} O$ of xylem and drainage samples were also analyzed using the Isoprime Isotope Ratio Mass Spectrometer (IRMS) at the LAMA laboratory of HydroSciences Montpellier, using the $\mathrm{CO}_{2}$ equilibration technique in dual inlet mode, yielding $\delta^{18} \mathrm{O}$ results with a $\pm 0.6 \%$ precision. The isotopic ratios in this study are expressed as:

$$
\delta^{18} O=\left[\left(R_{\text {sample }} / R_{\text {standard }}\right)-1\right] \times 1000 \%
$$

Where $R_{\text {sample }}$ and $R_{\text {standard }}$ are the heavy/light isotope ratios $\left({ }^{18} \mathrm{O} /{ }^{16} \mathrm{O}\right)$ of the sample and the standard (Vienna Standard Mean Ocean Water (VSMOW)), respectively. 


\section{Mixing model theory and uncertainty}

We assume that xylem water presents a mixed signal between deep and shallow water. If the origin of xylem water is linked to two sources without isotopic fractionation, the proportional contribution of each source may be resolved using a single isotope in a two-source system mass balance equation (Dawson 1993; Phillips and Ehleringer 1995):

$$
\delta_{x y l}=f_{s w} \cdot \delta_{s w}+f_{d w} \cdot \delta_{d w}
$$

Where $\delta_{x y l}$ is the plant xylem water $\delta^{18} \mathrm{O}$, and the proportions shallow water $\left(f_{s w}\right)$ and deep water $\left(f_{d w}\right)$ of the two sources have isotopic signatures $\delta_{s w}$ and $\delta_{d w}$, respectively. We performed a single isotope ratio two-source mass balance approach and calculated the fraction of deep water $\left(f_{d w}\right)$ contribution to xylem from Eq. 2 as:

$$
f_{d w}=\frac{\delta_{x y l}-\delta_{s w}}{\delta_{d w}-\delta_{s w}}
$$

We show the results of the ratio (figure 4) with uncertainties $W f_{s w}$ quantified at each date following Genereux (1998):

$$
W f_{s w}=\left\{\left[\frac{\delta_{d w}-\delta_{x y l}}{\left(\delta_{d w}-\delta_{s w}\right)^{2}} \cdot W \delta_{s w}\right]^{2}+\left[\frac{\delta_{x y l}-\delta_{s w}}{\left(\delta_{d w}-\delta_{s w}\right)^{2}} \cdot W \delta_{g w}\right]^{2}+\left[\frac{-1}{\delta_{d w}-\delta_{s w}} \cdot W \delta_{x y l}\right]^{2}\right\}
$$

Where $W \delta_{s w}, W \delta_{d w}, W \delta_{x y l}$ are the standard deviation for shallow water (precipitation and drainage), deep water (point $\mathrm{D}$ and point $\mathrm{C}$ or MtS and $\mathrm{Ctr}$ ) and xylem water (value of the sampled tree at each site), respectively.

Determining the origin of xylem water (shallow or deep water) based on water isotopes is possible only when these two mixing pools are significantly distinct. Because the two pools showed little difference in autumn and spring (figure 3), it was not possible to unravel the origin of the xylem signal for these two seasons.

\section{$\underline{3-\text { Results and interpretations }}$}

\section{Environmental data}

The two study years differed in terms of weather (Figure 3), as the summer of 2014 ranks in the $30 \%$ wettest years (return period $=3.4$ years), whereas 2015 was drier than average summer conditions and is classified among the $40 \%$ driest years (return period= 2.2 years) (Figure SI1). At Rustrel, during the 2014 growing season (May to September) the mean temperature was $19.9^{\circ} \mathrm{C}$, cumulative precipitation was $271 \mathrm{~mm}$, and mean vapor pressure deficit (VPD) was $857 \mathrm{hPa}$. By contrast, in 2015 the mean temperature was $21.2^{\circ} \mathrm{C}$, cumulative precipitation was only $101 \mathrm{~mm}$, and the VPD reached $1059 \mathrm{hPa}$. At Mont Ventoux the trend was similar, the mean temperature was $11.9^{\circ} \mathrm{C}$, cumulative precipitation was $499 \mathrm{~mm}$, and the VPD was $432 \mathrm{hPa}$ during the 2014 growing season, whereas in 2015 the mean temperature was $14^{\circ} \mathrm{C}$, cumulative precipitation was $370 \mathrm{~mm}$, and the VPD reached $632 \mathrm{hPa}$. 
Raw isotopic results: $\delta^{18} \mathrm{O}$ vs time

The temporal variation of isotopic signals for the years $2014-2015$ is presented in Figure 3 . The $\delta^{18} \mathrm{O}$ signal of the shallow resource is highly variable throughout the year because it is strongly affected by rainfall, which has a marked seasonal signal (Celle-Jeanton et al. 2001). The isotopic composition of rain is affected by several factors, including air temperature, the origin of atmospheric moisture, and rainfall intensity (Rozanski et al. 1992; Celle-Jeanton et al. 2004), which explains the high variability of the precipitation signal at both seasonal and rain event time scales. The isotopic composition of deep water has a more stable signal corresponding to the average precipitation signal during the recharge period. These results are consistent with those of Emblanch et al. (2003) and Lastenet (1994) on the same karst hydrosystem. Shallow water and deep water at Mont Ventoux are notably more depleted in ${ }^{18} \mathrm{O}$ than the water at Rustrel. This effect is consistent with the well-known altitudinal precipitation gradient (Rozanski et al. 1993; Lastenet 1994; Celle 2000).

The tree xylem water $\delta^{18} \mathrm{O}$ signal followed the shallow water signal during the summer of 2014 . By contrast, in 2015, the xylem signal deviated from the shallow water $\delta^{18} \mathrm{O}$ signal and approached the deep water signal as drought increased. This means that during the summer of 2015 , xylem water was a mixture of shallow and deep water, and that trees therefore exploited the deep water reservoir.
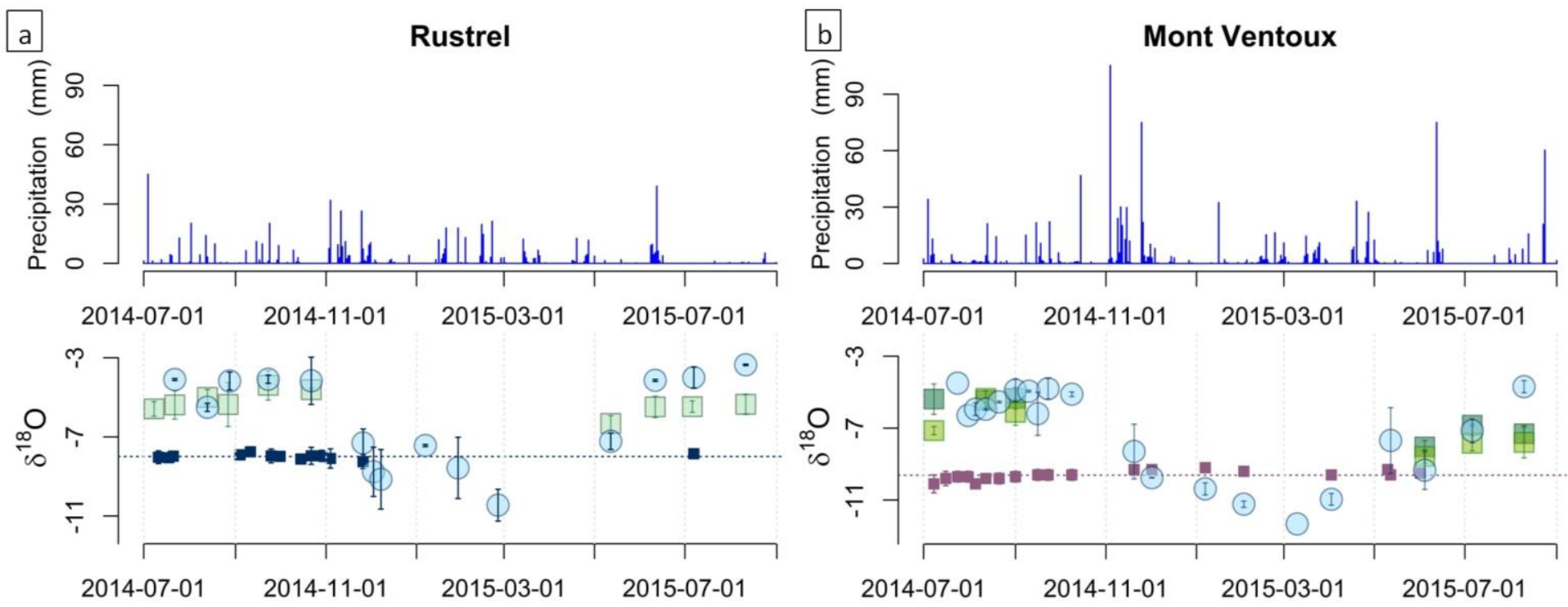

-... Deep water Rs $\square \quad$ Holm oak

-... Deep water Vx $\square$ Beech

Silver fir

Shallow water

Figure 3: Precipitation and evolution of isotopic signals of shallow water, deep water, and xylem water in 2014 and 2015, at a) Rustrel (Holm oak) and b) Mont Ventoux (Beech and Holm oak).

\section{Determination of plant water sources and water stress}

Significant temporal and inter-specific variations in the origin of xylem water were observed (Figure 4). All species of trees used comparatively deeper water in the drier summer of 2015 than in 2014. On average for all species, 9\% of xylem water came from deep water in 2014 as compared to $38 \%$ in 2015. We also noticed a broad variation among species, but this observation should be interpreted with caution because it is difficult to unravel the effects due to the site and that due to species. The two 
species on Mont Ventoux used less ground water compared to those at Rustrel. Beech used 7\% deep water on average during the 2014 summer, with a maximum of up to $13 \%$ at the end of summer and $46 \%$ in 2015 (summer average), with a maximum up to 63\% at the end of summer. On average, silver fir consumed $0 \%$ of deep water in 2014 compared to $27 \%$ in 2015 , and a maximum of $54 \%$ at the end of the summer of 2015. At Rustrel, holm oak consumed on average $21 \%$ deep water in 2014 and $40 \%$ in 2015 (up to $42 \%$ at the end of summer).

Leaf water potentials and cumulative precipitation corroborated the isotopic results and confirmed that the drought was considerably more severe in 2015 than in 2014. Leaf water potentials varied among species. Holm oak had the most highly variable water potentials $\left(\Psi_{\mathrm{P}}\right.$ and $\left.\Psi_{\mathrm{M}}\right)$ over time, with values always lower than the other two species; this species reached $\Psi_{\mathrm{P}}<-2.5 \mathrm{MPa}$ in July 2015 due to very low rainfall. Holm oak water potentials gradually decreased during the 2015 summer period. The difference between $\Psi_{\mathrm{P}}$ and $\Psi_{\mathrm{M}}(\Delta \Psi)$ also decreased during the same period. For beech, $\Psi_{\mathrm{P}}$ and $\Psi_{\mathrm{M}}$ potentials were relatively constant throughout the summer periods $\left(-0.3<\Psi_{\mathrm{P}}<-0.5 \mathrm{MPa}\right.$ for $\Psi_{\mathrm{P}}$ and $-1.5<\Psi_{\mathrm{M}}<-2 \mathrm{MPa}$ until July 2015 for $\Psi_{\mathrm{M}}$, respectively). However, during the severe drought of August 2015, $\Psi_{\mathrm{P}}$ almost doubled while $\Psi_{\mathrm{M}}$ increased. As a consequence, the $\Delta \Psi$ amplitude dropped sharply from 1.5 to $0.8 \mathrm{MPa}$, indicating decreased transpiration. The silver fir exhibited behavior distinct from the other species. Its water potentials $\left(\Psi_{\mathrm{P}}\right.$ and $\left.\Psi_{\mathrm{M}}\right)$ showed a more limited variation range. When drought came, $\Delta \Psi$ decreased regularly down to less than $0.5 \mathrm{MPa}$, because of increased $\Psi_{\mathrm{M}}$ and a concomitant decrease of $\Psi_{\mathrm{p}}$. 


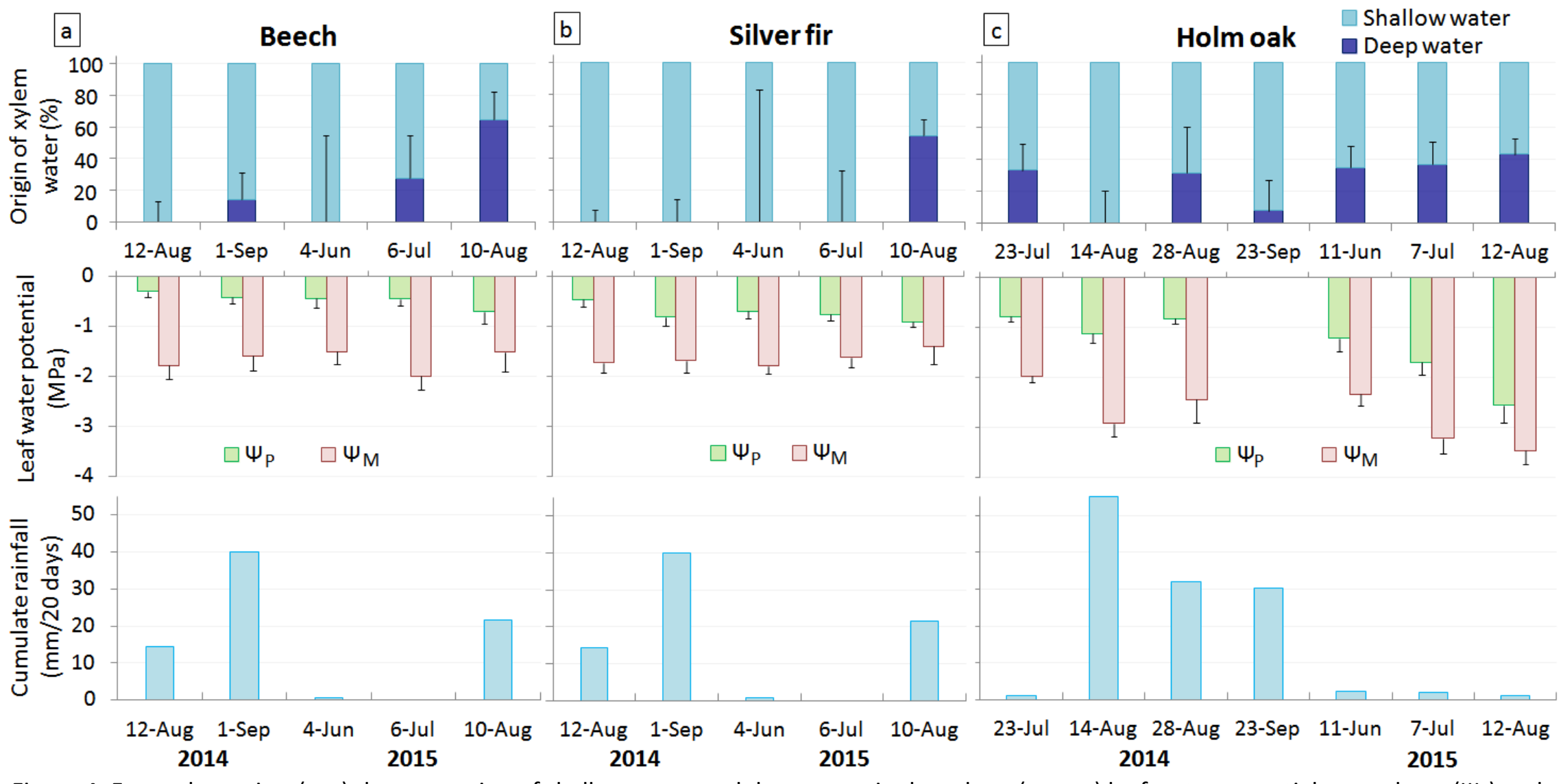

Figure 4: For each species, (top) the proportion of shallow water and deep water in the xylem, (center) leaf water potential at predawn ( $\left.\Psi_{\mathrm{p}}\right)$ and at midday $\left(\Psi_{\mathrm{M}}\right)$, and (bottom) cumulative precipitation during the 20 days preceding sampling, a) Beech, b) Silver fir, c) Holm oak. 


\section{4- Discussion}

The results of this paper show that when tree water stress increases, the fraction of deep water in xylem water increases. These results are consistent with those of other authors who have shown that trees take up water from deeper horizons during drought periods in a diverse range of ecosystems (e.g. Rambal (1984) and Barbeta et al. (2015) in Mediterranean forests; Le Roux et al. (1995) in savannas; Huang et al. (2011) and Liu et al. (2011) in tropical forest). Barbeta et al. (2015) showed that the groundwater proportion varies between 25 and 50\%. However, they did not identify any difference between the studied species. Our study shows that the three species monitored in this study exploit the deep water pool in different ways. Silver fir exploits deep water only under severe drought conditions. Beech exploits more deep water and earlier in the summer period. Holm oak exploits deep water for most of the summer period and the deep water contribution increases regularly during drought. Such differences between species can be associated with both (i) site characteristics, and (ii) species physiology.

i) The characteristics of the study sites are similar from a geological and pedological point of view, but the climatic conditions are significantly different. The Rustrel site, where holm oak grows, receives less rain and has higher potential evapotranspiration. This climatic context makes the Rustrel site more arid (Table 1; Fig. 3), which would constrain oak trees to rely more on deep water to sustain their water demand than trees at the other site. The Ventoux site is wetter and drought occurs later in the summer period. This is probably why beech and silver fir exploit mainly shallow water until the beginning of severe drought (August 2015).

ii) Physiology can also explain the differences between species. Beech and fir can be easily compared because they have the same geological, pedological, and climatic conditions at the Ventoux site. We identify differences in how these two cohabiting species use the deep water pool. Our findings contrast with previous isotopic results on a different system (Barbeta et al. 2015) but are consistent with other studies (Evaristo et al. 2017). The difference $\left(p\right.$-value $\left.=3.10^{-4}\right)$ in $\Psi_{\mathrm{p}}$ between silver fir $(-0.88 \mathrm{Mpa}$ on average) and beech $(-0.64 \mathrm{Mpa})$ indicate that they do not have access to the same total available water (TAW). Considering that the two species are present at the same site, we assume that these differences in TAW are due to differences in rooting depth. The systematically lower $\Psi_{\mathrm{P}}$ of silver fir means that its global rooting depth is lower. This hypothesis is consistent with isotopic results that show that silver fir takes almost no water from the deep water reserve except during severe drought (August 2015). Our results confirm the study conducted by Nourtier et al. (2014) at the same site, which attributed the high mortality of silver fir to drought. These authors highlighted with geophysics (ERT) that mortality was higher for individuals located on developed soil areas. They hypothesize that in areas where the shallow water reserve is large, trees live and grow without exploiting the deep water pool. These trees do not develop enough deep roots to exploit the deep water resource within karst vadose zone. As a result, they are more vulnerable to severe droughts that can cause massive tree mortality (Cailleret et al. 2012; 2014).

From a methodological point of view, we have shown that the combination of isotopic tracing and leaf water potential monitoring is relevant. Isotope tracing alone helps to determine the origin of water. Leaf water potential monitoring by itself makes it possible to evaluate the stress level related to water. By combining these two approaches, we have succeeded in showing that trees adapt their water uptake according to drought level. The greater the drought, the deeper the water that the trees exploit. 
This study has major implications for water balance modeling in karst settings. These models generally use TSAW measured in the field in pedologic pits. In karst areas, the measured TSAW does not represent the TAW reserve for trees. In fact, the TSAW represents only the superficial part of the TAW within the soil because the depth of pedologic pits is usually limited due to high rock content. Thus, the TSAW measured in the field cannot explain tree survival (Davi and Cailleret 2017) or the hydrodynamics of the studied karst system (Ollivier 2019). Modelers therefore increase the TAW to simulate a deep reservoir that presents a calibration difficulty. For example, they often multiply by a factor of 2 the field-measured TSAW (via pedologic pits) (Davi and Cailleret 2017). Ollivier et al. (2019) also increased TAW to better simulate the outflow simulated by a hydrogeological model of the Fontaine de Vaucluse system. These results show that trees extract water not only from the soil reservoir but also from a deeper reservoir. It remains difficult to quantify the exact contribution of this deep reservoir, but our results make it possible to qualitatively validate these assumptions. The goal of further studies will be to quantify this contribution by adding sap flow measurements or ecophysiological modeling to the current isotopic monitoring. In this way we could convert the water proportions as water volumes from each pool. These quantities would be easier to interpret and would be useful for ecophysiological and hydrogeological modeling. Another way to provide a better estimate of TAW, complementary to isotopic tracing, is to use geophysics. Geophysical tools such as magnetic resonance sounding (MRS) or electrical resistivity tomography (ERT) are promising tools for obtaining better estimates of TAW and its spatial variability at the plot scale (Carrière et al. accepted).

This paper shows that the interaction among climate, soil, and species determines deep water exploitation patterns. This observation needs to be repositioned in the climate change perspective because the impact of repeated and prolonged droughts on interactions between vegetation and groundwater resources is still poorly understood (Brolsma et al. 2010, Anderegg et al. 2013, Schäfer et al. 2014). Two extreme and opposite evolutions can be envisioned: i) droughts will cause massive dieback and defoliation of vegetation, which will limit the transpiration of vegetation cover, which can in turn increase infiltration and groundwater recharge. Or, ii) forests will adapt to drought, trees will consume less water quantitatively, but they will intercept and use a larger proportion of rainfall. In the latter case, with lower precipitation (P) and a higher ratio ET/P, groundwater recharge could decrease drastically. It is difficult to predict which scenario will occur, but it is likely that the future reality will follow an intermediate path between the two. Experiments on forest plots with rain exclusion seem to validate the second scenario (Barbeta et al. 2015). However, other studies using complementary approaches (e.g. surface based geophysics, remote sensing) need to be conducted to confirm these hypotheses at the broadest scales and in different ecological contexts. Importantly, our results suggest that deep water could constitute a much larger buffer than soil water alone. It is also essential to integrate human activities (e.g. planting new species, tree felling) to make these scenarios realistic. 


\section{5-Conclusions}

The combination of isotope tracing and leaf water potentials in a monitoring study conducted over two summer periods has provided useful results. The two methods provide complementary results that furnish new insights into water regulation during drought conditions in karst environments. We observed a concomitant decrease in $\Psi_{\mathrm{P}}$ and $\Delta \Psi$ as drought increased. This indicates the presence of transpiration regulation, a primary mechanism of drought response (Maseda and Fernandez 2006). The results of this paper also show that when tree water stress increases due to drought, the fraction of deep water in the xylem increases in comparison to the shallow water resource. This increased contribution of deep water was observed during the drought period (summer) for all three species. However, each species exploits this deep water reserve in a different way. This reflects different adaptation to drought among species. We show that it is essential to take into account the deep water resource in the calculation of total available water for transpiration. Taking this deep water into account will improve water balance modeling for ecological purposes (i.e. tree resistance to drought) and hydrogeological purposes (i.e. characterization of karst recharge). The scientific community must continue to study these interactions between vegetation cover and groundwater to better predict the evolution of these two interdependent entities.

Acknowledgments: This work benefited from fruitful discussions within the KARST observatory network (SNO KARST) initiative from the INSU/CNRS and OZCAR, which aims to strengthen knowledge sharing and promote cross-disciplinary research on karst systems at the national scale. We acknowledge $\mathrm{H}+$ for cofunding a part of this research. INRA supported this research in the framework of the metaprogramme Adaptation of Agriculture and Forests to Climate Change (AAFCC) of the French National Institute for Agricultural Research (INRA). 


\section{REFERENCES}

Abrams, M.D., 1990. Adaptations and responses to drought in Quercus species of North America. Tree physiology 7, 227-238.

Allen, C.D., Macalady, A.K., Chenchouni, H., Bachelet, D., McDowell, N., Vennetier, M., Kitzberger, T., Rigling, A., Breshears, D.D., Hogg, E.T., 2010. A global overview of drought and heat-induced tree mortality reveals emerging climate change risks for forests. Forest ecology and management 259, 660-684.

Anderegg, W.R., Kane, J.M., Anderegg, L.D., 2013. Consequences of widespread tree mortality triggered by drought and temperature stress. Nature climate change 3, 30.

Aquilina, L., Ladouche, B., Dörfliger, N., 2006. Water storage and transfer in the epikarst of karstic systems during high flow periods. Journal of Hydrology 327, 472-485. https://doi.org/10.1016/i.jhydrol.2005.11.054

Baize, D., Jabiol, B. (Eds.), 2011. Guide pour la description des sols. 2ème édition revue et corrigée [Guide for the description of soils. 2nd edition revised and corrected]. Editions INRA, Paris.

Bakalowicz, M., 2005. Karst groundwater: a challenge for new resources. Hydrogeology Journal 13, 148160. https://doi.org/10.1007/s10040-004-0402-9

Bakalowicz, M., Dörfliger, N., 2005. Ressources en eau du karst : un enjeu pour le bassin méditerranéen. Géosciences - l'eau souterraine [Karst water resources: an issue for the Mediterranean basin. Geosciences - groundwater]. Géosciences - I'eau souterraine BRGM 2, 26-31.

Barbeta, A., Jones, S.P., Clavé, L., Wingate, L., Gimeno, T.E., Fréjaville, B., Wohl, S., Ogée, J., in review. Hydrogen isotope fractionation affects the identification and quantification of tree water sources in a riparian forest. Hydrology and Earth System Sciences. https://doi.org/doi.org/10.5194/hess-2018$\underline{402}$

Barbeta, A., Mejía-Chang, M., Ogaya, R., Voltas, J., Dawson, T.E., Peñuelas, J., 2015. The combined effects of a long-term experimental drought and an extreme drought on the use of plant-water sources in a Mediterranean forest. Global Change Biology 21, 1213-1225. https://doi.org/10.1111/gcb.12785

Bariac, T., Gonzalez-Dunia, J., Katerji, N., Béthenod, O., Bertolini, J.M., Mariotti, A., 1994. Variabilité spatio-temporelle de la composition isotopique de l'eau $(18 \mathrm{O}, 2 \mathrm{H})$ dans le continuum sol-planteatmosphère 2. Approche en conditions naturelles [Spatiotemporal variability of the isotopic composition of water $(180,2 \mathrm{H})$ in the soil-plant-atmosphere continuum 2. Approach in natural conditions]. Chemical Geology 115, 317-333. https://doi.org/10.1016/0009-2541(94)90195-3

Bertrand, G., Masini, J., Goldscheider, N., Meeks, J., Lavastre, V., Celle-Jeanton, H., Gobat, J., Hunkeler, D., 2014. Determination of spatiotemporal variability of tree water uptake using stable isotopes $(\delta 180$, $\delta 2 \mathrm{H})$ in an alluvial system supplied by a high-altitude watershed, Pfyn forest, Switzerland. Ecohydrology 7, 319-333.

Blondel, T., Emblanch, C., Dudal, Y., Batiot-Guilhe, C., Travi, Y., Gaffet, S., 2010. Transit time environmental tracing from dissolved organic matter fluorescence properties in karstic aquifers. Application to different flows of Fontaine de Vaucluse experimental basin (SE France), in: Advances in Research in Karst Media. Springer, pp. 143-149. 
Bowling, D.R., Schulze, E.S., Hall, S.J., 2017. Revisiting streamside trees that do not use stream water: can the two water worlds hypothesis and snowpack isotopic effects explain a missing water source? Ecohydrology 10, e1771.

Bréda, N., Huc, R., Granier, A., Dreyer, E., 2006. Temperate forest trees and stands under severe drought: a review of ecophysiological responses, adaptation processes and long-term consequences. Annals of Forest Science 63, 625-644.

Brisson, N., Olioso, A., Clastre, P., 1993. Daily transpiration of field soybeans as related to hydraulic conductance, root distribution, soil potential and midday leaf potential. Plant Soil 154, 227-237. https://doi.org/10.1007/BF00012528

Brolsma, R., Van Vliet, M., Bierkens, M., 2010. Climate change impact on a groundwater-influenced hillslope ecosystem. Water Resources Research 46.

Brooks, J.R., Barnard, H.R., Coulombe, R., McDonnell, J.J., 2010. Ecohydrologic separation of water between trees and streams in a Mediterranean climate. Nature Geoscience 3, 100.

Cailleret, M., Nourtier, M., Amm, A., Durand-Gillmann, M., Davi, H., 2014. Drought-induced decline and mortality of silver fir differ among three sites in Southern France. Annals of Forest Science 71, 643657. https://doi.org/10.1007/s13595-013-0265-0

Cailleret, M., Nourtier, M., Amm, A., Gillmann, M., Davi, H., 2012. Comparison of drought-induced decline and mortality processes on silver fir among three sites in Provence, south-east France. Ann For Sci.

Canadell, J., Jackson, R., Ehleringer, J., Mooney, H., Sala, O., Schulze, E.-D., 1996. Maximum rooting depth of vegetation types at the global scale. Oecologia 108, 583-595.

Carrière, S.D., Chalikakis, K., Danquigny, C., Davi, H., Mazzilli, N., Ollivier, C., Emblanch, C., 2016. The role of porous matrix in water flow regulation within a karst unsaturated zone: an integrated hydrogeophysical approach. Hydrogeology Journal 24, 1905-1918.

Carrière, S.D., Chalikakis, K., Sénéchal, G., Danquigny, C., Emblanch, C., 2013. Combining Electrical Resistivity Tomography and Ground Penetrating Radar to study geological structuring of karst Unsaturated Zone. Journal of Applied Geophysics 94, 31-41. https://doi.org/10.1016/j.jappgeo.2013.03.014

Carrière, S.D., Danquigny, C., Davi, H., Chalikakis, K., Ollivier, C., Martin-StPaul, N.K., Emblanch, C., 2017. Process-Based Vegetation Models Improve Karst Recharge Simulation Under Mediterranean Forest, in: EuroKarst 2016, Neuchâtel. Springer, pp. 109-116.

Carrière, S.D., Ruffault, J., Pimont, F., Doussan, C., Simioni, G., Chalikakis, K., Limousin, J.-M., Scotti, I., Courdier, F., Cakpo, C.-B., Davi, H., St-Paul, N.K.M., 2019. Impact of local soil and subsoil conditions on inter-individual variations in tree responses to drought: insights from Electrical Resistivity Tomography. Science of The Total Environment 134247. https://doi.org/10.1016/j.scitotenv.2019.134247

Celle, H., 2000. Caractérisation des précipitations sur le pourtour de la Méditerranée occidentale Approche isotopique et chimique [Characterization of rainfall in the western Mediterranean region - Isotopic and Chemical approach]. Université d'Avignon, Avignon.

Celle-Jeanton, H., Gonfiantini, R., Travi, Y., Sol, B., 2004. Oxygen-18 variations of rainwater during precipitation: application of the Rayleigh model to selected rainfalls in Southern France. Journal of Hydrology 289, 165-177. 
Celle-Jeanton, H., Zouari, K., Travi, Y., Daoud, A., 2001. Caractérisation isotopique des pluies en Tunisie. Essai de typologie dans la région de Sfax [Isotopic characterization of rainfall in Tunisia. Typology test in the region of Sfax]. Comptes Rendus de I'Académie des Sciences-Series IIA-Earth and Planetary Science 333, 625-631.

Chaves, M.M., Pereira, J.S., Maroco, J., Rodrigues, M.L., Ricardo, C.P.P., Osório, M.L., Carvalho, I., Faria, T., Pinheiro, C., 2002. How plants cope with water stress in the field? Photosynthesis and growth. Annals of botany 89, 907-916.

Chen, Z., Auler, A.S., Bakalowicz, M., Drew, D., Griger, F., Hartmann, J., Jiang, G., Moosdorf, N., Richts, A., Stevanovic, Z., Veni, G., Goldscheider, N., 2017. The World Karst Aquifer Mapping project: concept, mapping procedure and map of Europe. Hydrogeology Journal 25, 771-785. https://doi.org/10.1007/s10040-016-1519-3

Cognard-Plancq, A., Gevaudan, C., Emblanch, C., 2006. Historical monthly rainfall-runoff database on Fontaine de Vaucluse karst system: review and lessons, in: Karst, Cambio Climatico y Aguas Submediterraneas. Duran J.J., Andreo B., Carrasco F., pp. 465-475.

Cruiziat, P., Cochard, H., Améglio, T., 2002. Hydraulic architecture of trees: main concepts and results. Annals of Forest Science 59, 723-752. https://doi.org/10.1051/forest:2002060

Cvijic, I., 1960. La géographie des terrains calcaires [The geography of limestone terrains]. Académie des sciences et des arts serbe 147-168.

Davi, H., Cailleret, M., 2017. Assessing drought-driven mortality trees with physiological process-based models. Agricultural and forest meteorology 232, 279-290.

Dawson, T.E., 1993. Hydraulic lift and water use by plants: implications for water balance, performance and plant-plant interactions. Oecologia 95, 565-574.

Dawson, T.E., Ehleringer, J.R., 1991. Streamside trees that do not use stream water. Nature 350, 335-337.

Ehleringer, J., Dawson, T., 1992. Water uptake by plants: perspectives from stable isotope composition. Plant, Cell \& Environment 15, 1073-1082.

Ehleringer, J., Osmond, C., 1989. Stable isotopes, in: Plant Physiological Ecology: Field Techniques and Instrumentation. Pearcy RW, Ehleringer JR, Mooney HA, Rundel PW, London, UK, pp. 281-300.

Ellsworth, P.Z., Williams, D.G., 2007. Hydrogen isotope fractionation during water uptake by woody xerophytes. Plant and Soil 291, 93-107.

Emblanch, C., Zuppi, G.M., Mudry, J., Blavoux, B., Batiot, C., 2003. Carbon 13 of TDIC to quantify the role of the unsaturated zone: the example of the Vaucluse karst systems (Southeastern France). Journal of Hydrology 279, 262-274. https://doi.org/10.1016/s0022-1694(03)00180-x

Evaristo, J., Jasechko, S., McDonnell, J.J., 2015. Global separation of plant transpiration from groundwater and streamflow. Nature 525, 91-94.

Evaristo, J., McDonnell, J.J., Clemens, J., 2017. Plant source water apportionment using stable isotopes: A comparison of simple linear, two-compartment mixing model approaches. Hydrological Processes 31, 3750-3758. https://doi.org/10.1002/hyp.11233

Evaristo, J., McDonnell, J.J., Scholl, M.A., Bruijnzeel, L.A., Chun, K.P., 2016. Insights into plant water uptake from xylem-water isotope measurements in two tropical catchments with contrasting moisture conditions. Hydrological Processes 30, 3210-3227.

Ford, D.C., Williams, P.W., 2007. Karst hydrogeology and geomorphology, Chapman and Hall. ed. John Wiley and Sons, Chichester. 
Garry, B., Blondel, T., Emblanch, C., Sudre, C., Bilgot, S., Cavaillou, A., Boyer, D., Auguste, M., 2008. Contribution of artificial galleries to the knowledge of karstic system behaviour in addition to natural cavern data. Int. J. Speleol. 37, 75-82.

Genereux, D., 1998. Quantifying uncertainty in tracer-based hydrograph separations. Water Resources Research 34, 915-919.

Geris, J., Tetzlaff, D., McDonnell, J.J., Soulsby, C., 2017. Spatial and temporal patterns of soil water storage and vegetation water use in humid northern catchments. Science of the Total Environment 595, 486-493.

Hartmann, A., Goldscheider, N., Wagener, T., Lange, J., Weiler, M., 2014. Karst water resources in a changing world: Review of hydrological modeling approaches. Reviews of Geophysics 52, 218-242. https://doi.org/10.1002/2013RG000443

Huang, Y., Li, X., Zhang, Z., He, C., Zhao, P., You, Y., Mo, L., 2011. Seasonal changes in Cyclobalanopsis glauca transpiration and canopy stomatal conductance and their dependence on subterranean water and climatic factors in rocky karst terrain. Journal of hydrology 402, 135-143.

IAEA, 2014. IAEA/GNIP precipitation sampling guide [WWW Document]. URL http://wwwnaweb.iaea.org/napc/ih/documents/other/gnip manual v2.02 en hq.pdf (accessed 1.23.19).

Johnson, D.M., Sherrard, M.E., Domec, J.-C., Jackson, R.B., 2014. Role of aquaporin activity in regulating deep and shallow root hydraulic conductance during extreme drought. Trees 28, 1323-1331.

Jourde, H., Massei, N., Mazzilli, N., Binet, S., Batiot-Guilhe, C., Labat, D., Steinmann, M., Bailly-Comte, V., Seidel, J., Arfib, B., 2018. SNO KARST: A French network of observatories for the multidisciplinary study of critical zone processes in karst watersheds and aquifers. Vadose Zone Journal 17.

Keenan, R.J., 2015. Climate change impacts and adaptation in forest management: a review. Annals of Forest Science 72, 145-167.

Lastennet, R., 1994. Influence de la zone non saturée sur le fonctionnement des systèmes karstiques. Mise en évidence dans les sources du Nord-Vaucluse [Influence of the unsaturated zone on the functioning of karst systems. Observations from Northern Vaucluse springs.]. Université d'Avignon et des Pays de Vaucluse.

Le Roux, X., Bariac, T., Mariotti, A., 1995. Spatial partitioning of the soil water resource between grass and shrub components in a West African humid savanna. Oecologia 104, 147-155.

Limousin, J., Misson, L., Lavoir, A., Martin, N.K., Rambal, S., 2010. Do photosynthetic limitations of evergreen Quercus ilex leaves change with long-term increased drought severity? Plant, Cell \& Environment 33, 863-875.

Limousin, J.M., Rambal, S., Ourcival, J.M., Rocheteau, A., Joffre, R., Rodriguez-Cortina, R., 2009. Long-term transpiration change with rainfall decline in a Mediterranean Quercus ilex forest. Global Change Biology 15, 2163-2175. https://doi.org/10.1111/j.1365-2486.2009.01852.x

Lin, G., da Sternberg, L.S.L., 1993. Hydrogen isotopic fractionation by plant roots during water uptake in coastal wetland plants, in: Stable Isotopes and Plant Carbon-Water Relations. Elsevier, pp. 497-510.

Liu, C., Liu, Y., Guo, K., Fan, D., Li, G., Zheng, Y., Yu, L., Yang, R., 2011. Effect of drought on pigments, osmotic adjustment and antioxidant enzymes in six woody plant species in karst habitats of southwestern China. Environmental and Experimental Botany 71, 174-183.

Martel, E., 1902. Sur l'origine et l'âge de la Fontaine de Vaucluse [On the origin and age of the Fontaine de Vaucluse]. C. R. Acad. Sci. 134, 256-259. 
Martínez-Vilalta, J., Poyatos, R., Aguadé, D., Retana, J., Mencuccini, M., 2014. A new look at water transport regulation in plants. New Phytologist 204, 105-115.

Martín-Gómez, P., Barbeta, A., Voltas, J., Peñuelas, J., Dennis, K., Palacio, S., Dawson, T.E., Ferrio, J.P., 2015. Isotope-ratio infrared spectroscopy: a reliable tool for the investigation of plant-water sources? New Phytologist.

Martin-StPaul, N., Delzon, S., Cochard, H., 2017. Plants resistance to drought relies on early stomata closure. BioArxiv. https://doi.org/10.1101/099531

Martin-StPaul, N.K., Limousin, J., Vogt-Schilb, H., Rodríguez-Calcerrada, J., Rambal, S., Longepierre, D., Misson, L., 2013. The temporal response to drought in a Mediterranean evergreen tree: comparing a regional precipitation gradient and a throughfall exclusion experiment. Global Change Biology 19, 2413-2426.

Maseda, P.H., Fernández, R.J., 2006. Stay wet or else: three ways in which plants can adjust hydraulically to their environment. Journal of Experimental Botany 57, 3963-3977.

McElrone, A.J., Pockman, W.T., Martínez-Vilalta, J., Jackson, R.B., 2004. Variation in xylem structure and function in stems and roots of trees to $20 \mathrm{~m}$ depth. New phytologist 163, 507-517.

Murray, B.B.R., Zeppel, M.J., Hose, G.C., Eamus, D., 2003. Groundwater-dependent ecosystems in Australia: It's more than just water for rivers. Ecological Management \& Restoration 4, 110-113.

Naumburg, E., Mata-Gonzalez, R., Hunter, R.G., Mclendon, T., Martin, D.W., 2005. Phreatophytic vegetation and groundwater fluctuations: a review of current research and application of ecosystem response modeling with an emphasis on Great Basin vegetation. Environmental Management 35, $726-740$.

Nourtier, M., Chanzy, A., Cailleret, M., Yingge, X., Huc, R., Davi, H., 2014. Transpiration of silver Fir (Abies alba mill.) during and after drought in relation to soil properties in a Mediterranean mountain area. Annals of forest science 71, 683-695.

Ogle, K., Tucker, C., Cable, J.M., 2014. Beyond simple linear mixing models: Process-based isotope partitioning of ecological processes. Ecological applications 24, 181-195.

Olioso, A., Carlson, T.N., Brisson, N., 1996. Simulation of diurnal transpiration and photosynthesis of a water stressed soybean crop. Agricultural and Forest Meteorology 81, 41-59.

Ollivier, C., Chalikakis, K., Mazzilli, N., Kazakis, N., Lecomte, Y., Danquigny, C., Emblanch, C., 2019. Challenges and Limitations of Karst Aquifer Vulnerability Mapping Based on the PaPRIKa MethodApplication to a Large European Karst Aquifer (Fontaine de Vaucluse, France). Environments 6, 39.

Ollivier, C., Olioso, A., Mazzilli, N., Chalikakis, K., Carriere, S.D., Danquigny, C., Emblanch, C., 2019. Karst recharge-discharge semi-distributed model to assess spatial variability of flows. Science of the Total Environment, in press.

Ollivier, C., 2019. Caractérisation et spatialisation de la recharge des systèmes karstiques. Application au système de la Fontaine de Vaucluse, France [Characterization and spatialization of karstic system recharge. Application to the system of Fontaine de Vaucluse, Erance]. Avignon https://prodinra.inra.fr/?locale=fr\#! ConsultNotice:472619

Parnell, A.C., Inger, R., Bearhop, S., Jackson, A.L., 2010. Source partitioning using stable isotopes: coping with too much variation. PloS one 5, e9672. 
Perrin, J., Jeannin, P.-Y., Zwahlen, F., 2003. Epikarst storage in a karst aquifer: a conceptual model based on isotopic data, Milandre test site, Switzerland. Journal of Hydrology 279, 106-124. https://doi.org/10.1016/s0022-1694(03)00171-9

Phillips, S.L., Ehleringer, J.R., 1995. Limited uptake of summer precipitation by bigtooth maple (Acer grandidentatum Nutt) and Gambel's oak (Quereus gambelii Nutt). Trees 9, 214-219.

Plaut, J.A., Yepez, E.A., Hill, J., Pangle, R., Sperry, J.S., Pockman, W.T., Mcdowell, N.G., 2012. Hydraulic limits preceding mortality in a piñon-juniper woodland under experimental drought: Hydraulic limits in a piñon-juniper woodland. Plant, Cell \& Environment 35, 1601-1617. https://doi.org/10.1111/j.1365-3040.2012.02512.x

Querejeta, J.I., Estrada-Medina, H., Allen, M.F., Jiménez-Osornio, J.J., 2007. Water source partitioning among trees growing on shallow karst soils in a seasonally dry tropical climate. Oecologia 152, 2636.

Rambal, S., 1984. Water balance and pattern of root water uptake by a Quercus coccifera L. evergreen scrub. Oecologia 8.

Rozanski, K., Araguás-Araguás, L., Gonfiantini, R., 1993. Isotopic Patterns in Modern Global Precipitation, in: Climate Change in Continental Isotopic Records. American Geophysical Union, pp. 1-36. https://doi.org/10.1029/GM078p0001

Rozanski, K., Araguás-Araguás, L., Gonfiantini, R., 1992. Relation Between Long-Term Trends of Oxygen-18 Isotope Composition of Precipitation and Climate. Science, New Series 258, 981-985.

Schäfer, K., Renninger, H., Clark, K., Medvigy, D., 2014. Hydrological responses to defoliation and drought of an upland oak/pine forest. Hydrological processes 28, 6113-6123.

Scholander, P.F., Bradstreet, E.D., Hemmingsen, E., Hammel, H., 1965. Sap pressure in vascular plants: negative hydrostatic pressure can be measured in plants. Science 148, 339-346.

Spies, T.A., Giesen, T.W., Swanson, F.J., Franklin, J.F., Lach, D., Johnson, K.N., 2010. Climate change adaptation strategies for federal forests of the Pacific Northwest, USA: ecological, policy, and socioeconomic perspectives. Landscape ecology 25, 1185-1199.

Sternberg, L. da S.L., Swart, P.K., 1987. Utilization of freshwater and ocean water by coastal plants of southern Florida. Ecology 68, 1898-1905.

Tardieu, F., Katerji, N., Bethenod, O., Hamard, P., Quétin, P., Bal, P., 1990. Relations entre l'état hydrique du sol, le potentiel de base et d'autres indicateurs de la contrainte hydrique chez le maïs [Relationship between soil moisture status, predawn potential and other indicators of water stress in maize]. Agronomie 10, 617-626.

Taylor-Laine, S.D., Espino, S., Downey, A., Schenk, H.J., 2016. Testing a new method for in situ measurements of stem hydraulic conductance in intact plants [WWW Document]. URL http://ictinternational.com/casestudies/testing-a-new-method-for-in-situ-measurements-of-stemhydraulic-conductance-in-intact-plants/ (accessed 1.15.19).

Turner, N.C., 1981. Techniques and experimental approaches for the measurement of plant water status. Plant and soil 58, 339-366.

Van Hees, A., 1997. Growth and morphology of pedunculate oak (Quercus robur L) and beech (Fagus sylvatica L) seedlings in relation to shading and drought. Presented at the Annales des Sciences Forestières, EDP Sciences, pp. 9-18. 
Vargas, A.I., Schaffer, B., Yuhong, L., Sternberg, L. da S.L., 2017. Testing plant use of mobile vs immobile soil water sources using stable isotope experiments. New Phytologist 215, 582-594.

Walker, C.D., Brunel, J.P., 1990. Examining evapotranspiration in a semi-arid region using stable isotopes of hydrogen and oxygen. Journal of Hydrology 118, 55-75. https://doi.org/10.1016/00221694(90)90250-2

West, A.G., Patrickson, S.J., Ehleringer, J.R., 2006. Water extraction times for plant and soil materials used in stable isotope analysis. Rapid Communications in Mass Spectrometry 20, 1317-1321. https://doi.org/10.1002/rcm.2456

Zimmermann, U., Münnich, K., Roether, W., Kreutz, W., Schubach, K., Siegel, O., 1966. Tracers determine movement of soil moisture and evapotranspiration. Science 152, 346-347. 


\section{SUPPLEMENTARY INFORMATION}

SI1: Climatic analysis

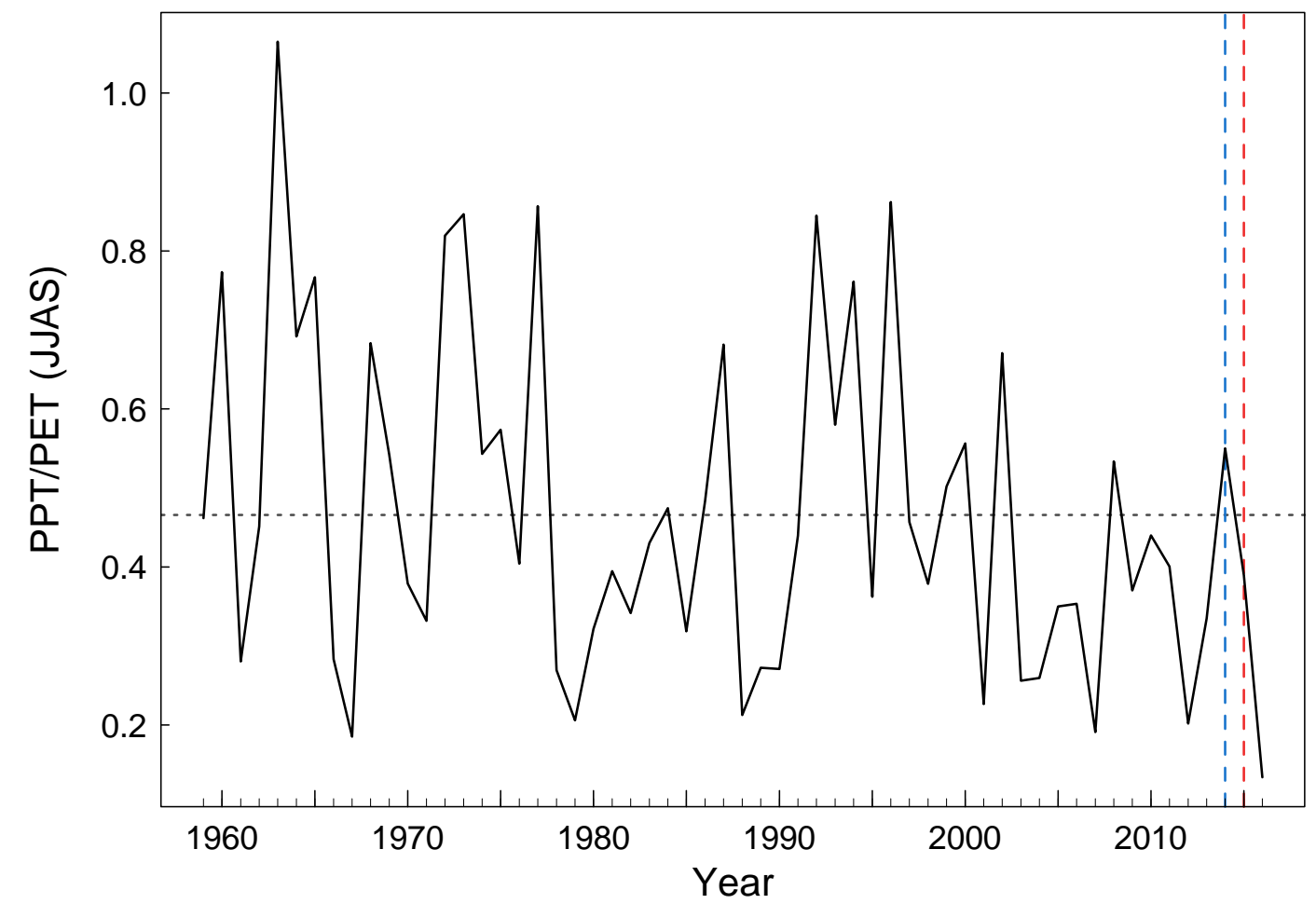

Figure SI1: Summer ratio between annual rainfall and potential evapotranspiration (PPT/PET) at the study site for the period from 1959 to 2016, for the months of June, July, August, September (JJAS).

Lower values of the ratio correspond to drier years. The dotted horizontal line indicates the mean of the PPT/PET ratio over the study period. The years 2014 and 2015 used as reference in our analyses are represented by vertical blue and red lines, respectively. Daily weather datasets used to derive these estimations were extracted from the SAFRAN climate reanalysis (Vidal et al. 2010) at an 8km spatial resolution. PET was estimated using the Penman-Monteith formula. 
SI2: Rain and drainage water collecting system

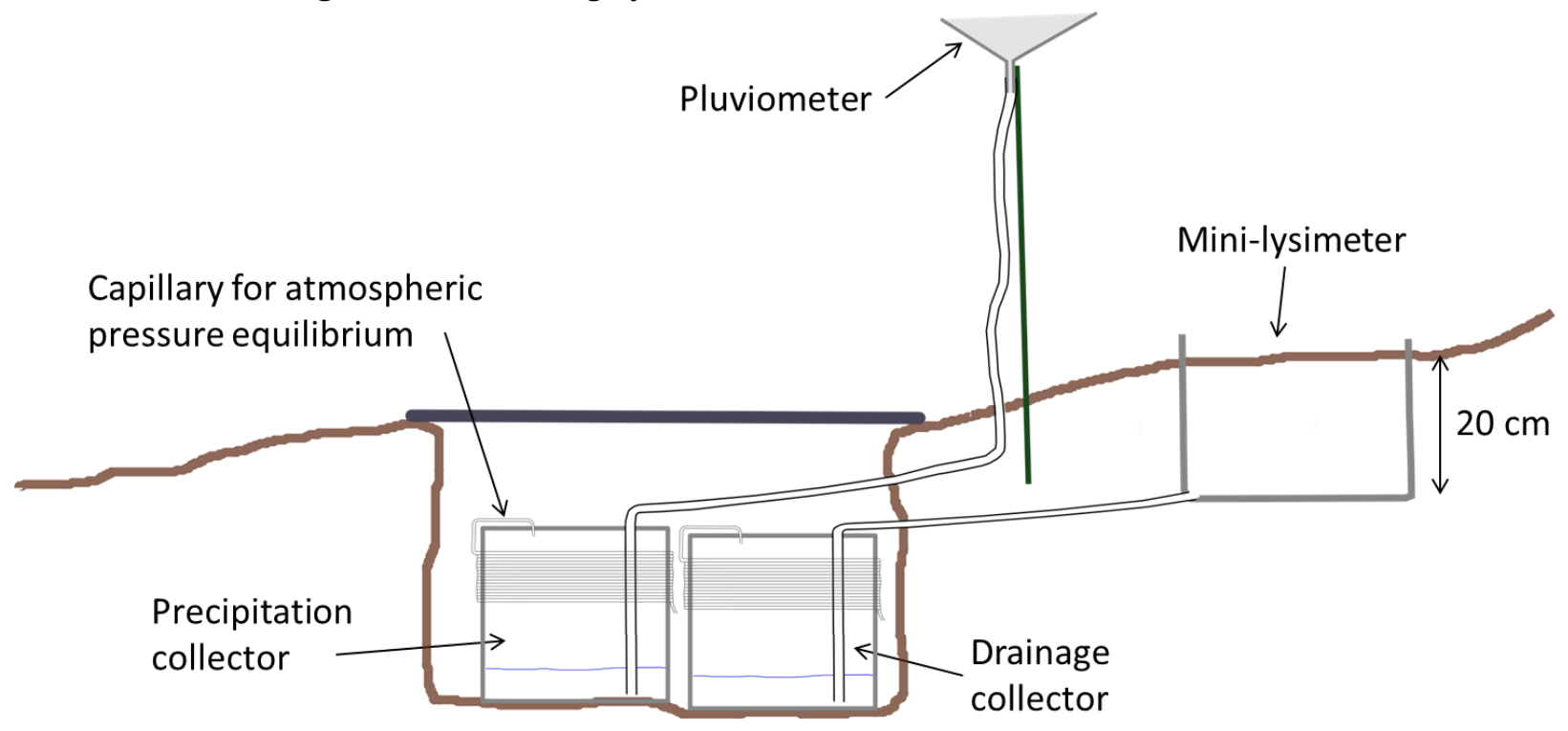

